\title{
Halotolerant Collagenolytic Activity of Achromobacter iophagus
}

\author{
By R. L. WELTON AND D. R. WOODS \\ Department of Botany and Microbiology, Rhodes University, \\ Grahamstown, Republic of South Africa
}

(Received 23 October 1972)

S U M MARY

\begin{abstract}
A strain of Achromobacter iophagus isolated from cured hides was shown to lyse collagen rapidly under aerobic conditions. Changes of temperature, $\mathrm{pH}, \mathrm{NaCl}$ or collagen concentration affected either the maximum rate of collagen lysis or the lag before this rate was attained, or both. Collagenolytic activity occurred in 0.85 to $10 \%(\mathrm{w} / \mathrm{v}) \mathrm{NaCl}$.
\end{abstract}

\section{INTRODUCTION}

Anaerobic collagenolytic activity by bacteria has been demonstrated in four Clostridium spp., three Bacterioides spp. and one strain of Staphylococcus aureus (Waldvogel \& Swartz, 1969). Exhaustive studies have been made of the collagenase from Clostridium histolyticum (Kono, I968; Schaub \& Strauch, I968). Recently, aerobic collagenolytic activity was demonstrated in two strains of Pseudomonas, three of Bacillus and eight of Achromobacter (Adamcic \& Clark, 1970; Thomson, Woods \& Welton, 1972). There are no reported investigations of the aerobically produced collagenases.

Collagenolytic activity by hide bacteria is regarded as the cause of leather decay and thus a knowledge of the conditions under which these bacteria can degrade collagen is important to the hide and skin industry. The present study of a vigorously collagenolytic hide bacterium aimed to determine the optimal conditions for collagenolytic activity with a view to purification of the collagenase.

\section{METHODS}

All percentage compositions are $\mathrm{w} / \mathrm{v}$ and all nutrients are Difco (Detroit, Michigan, U.S.A.) unless stated otherwise.

Source and identification. The bacterium was isolated from a batch of South African cured hides whose bacterial population possessed a high collagenolytic activity (Woods, Welton, Thomson \& Cooper, I972). It was identified according to Bergey's Manual of Determinative Bacteriology (Breed, Murray \& Smith, 1957) and A Guide to the Identification of the Genera of Bacteria with Methods and Digest of Genetic Characteristics (Skerman, 1967).

Media. The bacterium was maintained on a complex medium containing $(\mathrm{g} / \mathrm{l})$ : casein hydrolysate (British Drug Houses, Poole, Dorset and Merck AG, Darmstadt, Germany), I 7.0; glucose, 5.0; glycerol, I0.0; $\mathrm{NaCl}, 23.4 ; \mathrm{Na}_{2} \mathrm{SO}_{3}, 0 . \mathrm{I}$; nutrient broth, 8.0; soytone, 3.0; tryptone, 0.5 ; vitamin-free Casamino acids, 0.5 ; yeast extract, 2.0 ; and agar, 15.0 . The $\mathrm{pH}$ was adjusted to 7.6 with $\mathrm{NaOH}$. Owing to the rapid spreading of the bacterium, this medium was not suitable for isolating clones. Discrete colonies were obtained on a medium consisting of: minimal salts solution, I $25 \mathrm{ml}$; glucose, $2 \mathrm{~g}$; agar, $\mathrm{I} 5 \mathrm{~g}$; distilled water to I 1 . The minimal salts solution contained $(\mathrm{g} / \mathrm{l}): \mathrm{KH}_{2} \mathrm{PO}_{4}, 8 ; \mathrm{K}_{2} \mathrm{HPO}_{4}, 24 ; \mathrm{MgSO}_{4} \cdot 7 \mathrm{H}_{2} \mathrm{O}, 0.8 ; \mathrm{Na}_{2} \mathrm{SO}_{4}$ (anhydrous), $\mathrm{I} 6 ; \mathrm{NH}_{4} \mathrm{Cl}, 40$; and $\mathrm{NH}_{4} \mathrm{NO}_{3}, 8$. 
Table I. Characteristics of collagenolytic Achromobacter iophagus

$\begin{array}{lc}\text { Gram-negative rod } & + \\ \text { Length }(\mu \mathrm{m}) & 2 \cdot 2 \text { to } 7 \cdot 2 \\ \text { Width }(\mu \mathrm{m}) & 1 \cdot 0 \text { to } \mathrm{r} \cdot 8 \\ \text { Flagella } & \text { Many, peritrichous } \\ \text { Pigmentation } & - \\ \text { Endospores } & - \\ \text { Capsule } & + \\ \text { Facultative aerobe } & - \\ \text { Autotrophic } & + \\ \text { Halotolerant }(\mathrm{NaCl} \text { range } 0 \cdot 85 \text { to } 10 \% & \\ \quad \text { optimal growth at } 2 \cdot 34 \%) & + \\ \text { Indole produced } & + \\ \text { Catalase produced } & - \\ \text { Oxidase produced } & + \\ \text { Nitrates reduced to nitrites } & - \\ \text { Acid or alkali produced from litmus milk } & - \\ \text { Acid, but no gas, produced from } & + \\ \text { glucose, mannose, sucrose and glycerol } & \\ \text { Acid from lactose } & - \\ \text { Hydrolysis of gelatin and starch } & + \\ \text { Hydrolysis of cellulose and chitin } & - \\ & \quad-, \text { Positive or negative reaction. }\end{array}$

Collagenolytic activity assays. Collagenolytic activity was measured by determining released amino acids, expressed as $\mu$ moles glycine $/ \mathrm{ml}$, by the method of Adamcic \& Clark ( 970 ). Collagen reaction mixtures consisted of a suspension of bovine Achilles tendon collagen (Boehringer, Männheim, Germany) in $6 \mathrm{ml}$ of tris- $\mathrm{HCl}$ or tris-maleate buffer containing $\mathrm{NaCl}$ and $0.002 \mathrm{M}^{-\mathrm{CaCl}_{2}}$, at concentrations of $0.2,0.5,1.5,3.5$ and $5.5 \mathrm{mg} / \mathrm{ml}$ with $\mathrm{NaCl}$ concentrations of $0.85,2.34,4.0,7 \cdot 0,10.0$ and $13.0 \%$. Tris-maleate buffer was used to achieve $\mathrm{pH}$ values of $6 \cdot 0$ to $7 \cdot 6$ while tris- $\mathrm{HCl}$ was used for values of $7 \cdot 2$ to $9 \cdot 2$. The final concentration of tris in all buffers was $0 . \mathrm{I} \mathrm{M}$. From an overnight plate culture of the bacterium a buffered, washed suspension containing approximately $10^{9}$ bacteria $/ \mathrm{ml}$ was prepared. Samples $(0.2 \mathrm{ml})$ of this suspension were added to reaction mixtures and incubated aerobically at $\mathrm{I} 5,20,25,30$ and $35^{\circ} \mathrm{C}$. Experimental controls comprized collagen suspensions alone and bacteria in buffer without collagen. All reaction mixtures and controls were duplicated and two assays were made from each at the various times.

\section{RESULTS \\ Identification}

The characteristics of the bacterium are shown in Table I (identified as Achromobacter iophagus).

\section{Collagenolytic activity}

Control values shown in Fig. I to 4 are the highest values at each time interval. For clarity, all time zero symbols have been omitted. The least significant difference (L.S.D.) values for Fig. I and 3 are based on data for 4 days while those for Fig. 2 and Fig. 4 are based on data for 5 and 3 days respectively.

Effect of temperature. The effect of incubation at different temperatures is shown in Fig. I. There was no significant difference between $30^{\circ}$ and $35^{\circ} \mathrm{C}$. These temperatures produced the 


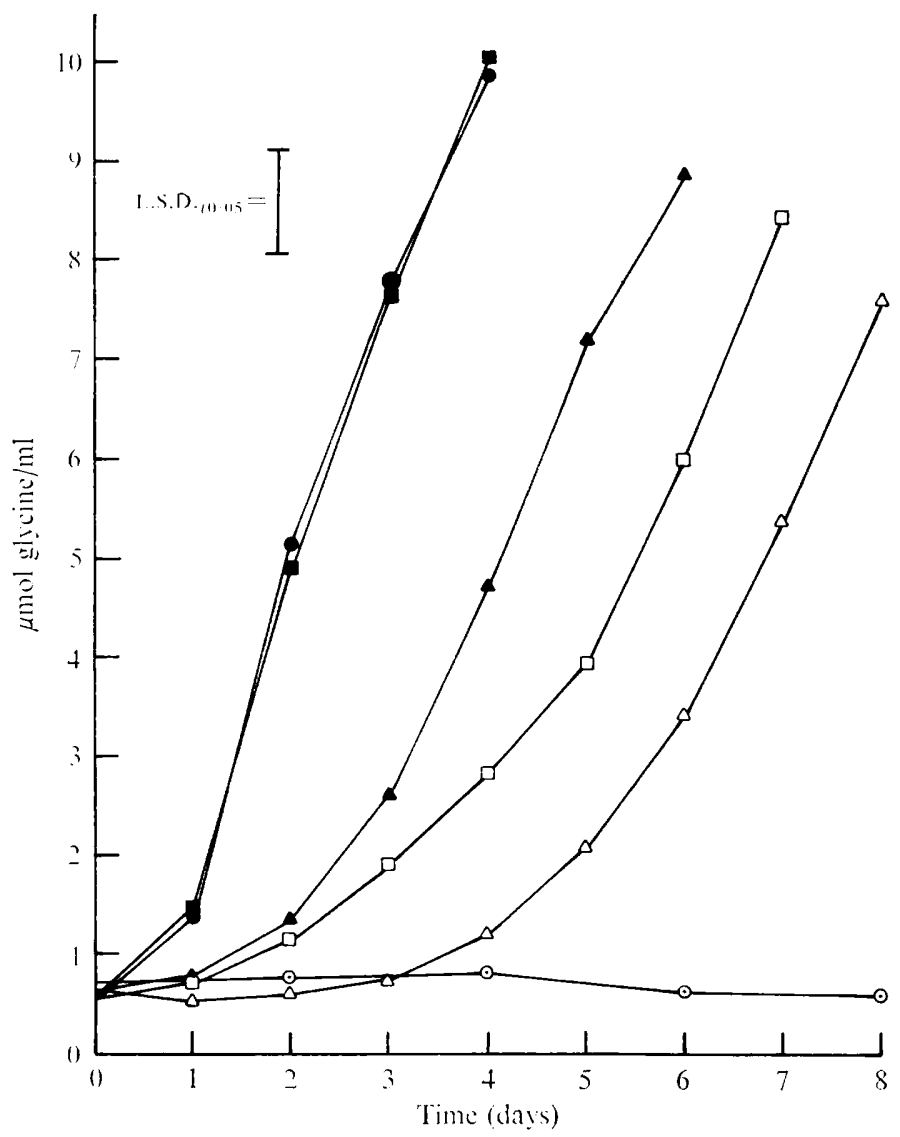

Fig. I. Collagenolytic activity of Achromobacter iophagus at different temperatures. Reaction mixtures contained $2 \cdot 34 \% \mathrm{NaCl}$ and $\mathrm{I} \cdot 5 \mathrm{mg}$ collagen $\mathrm{ml}$ of buffer at $\mathrm{pH} 7 \cdot 6 . \triangle-\triangle$, I $5{ }^{\circ} \mathrm{C} ; \square-\square$, $20{ }^{\circ} \mathrm{C} ; \boldsymbol{\Delta}-\boldsymbol{\Delta}, 25^{\circ} \mathrm{C} ; \boldsymbol{\square}, 30 \mathrm{C} ;-\bigcirc, 35^{\circ} \mathrm{C} ; \odot-\odot$, control. The activity is shown as amino acids (expressed as $\mu \mathrm{mol}$ glycine) released from collagen under the conditions described in the text.

highest maximum rate of collagen lysis and the shortest lag period before this rate was attained. As the temperature was reduced the maximum rate of lysis decreased and the lag period increased. Even at $15{ }^{\circ} \mathrm{C}$, however, a rapid rate of collagen breakdown was reached within approximately 6 days.

Effect of $\mathrm{NaCl}$ concentration. These results are presented in Fig. 2. Collagenolytic activity occurred between $0.85 \%$ and $10.0 \% \mathrm{NaCl}$ but was inhibited by $13.0 \% \mathrm{NaCl}$. The maximum rate of collagen degradation occurred at $2.34 \% \mathrm{NaCl}$ and the least lag occurred at $2.34 \%$ $\mathrm{NaCl}$. At $\mathrm{NaCl}$ concentrations above $2.34 \%$ the maximum rate decreased and the lag period increased. The collagenolytic activities at $0.85 \%$ and $4.00 \% \mathrm{NaCl}$ were not significantly different.

Effect of $p H$. Fig. 3 shows the effect of $\mathrm{pH}$ over the range $\mathrm{pH} 6 \cdot 0$ to $9 \cdot 2$. No significant differences were discerned in the overall data for $\mathrm{pH} 7.2,7.6$ and 8.0 , at which values the maximum rate of collagen breakdown was highest and the lag period was shortest. With increasing deviation from $\mathrm{pH} 7 \cdot 2$ to $8 \cdot 0$ the maximum rate of collagen lysis decreased and the lag period increased. 


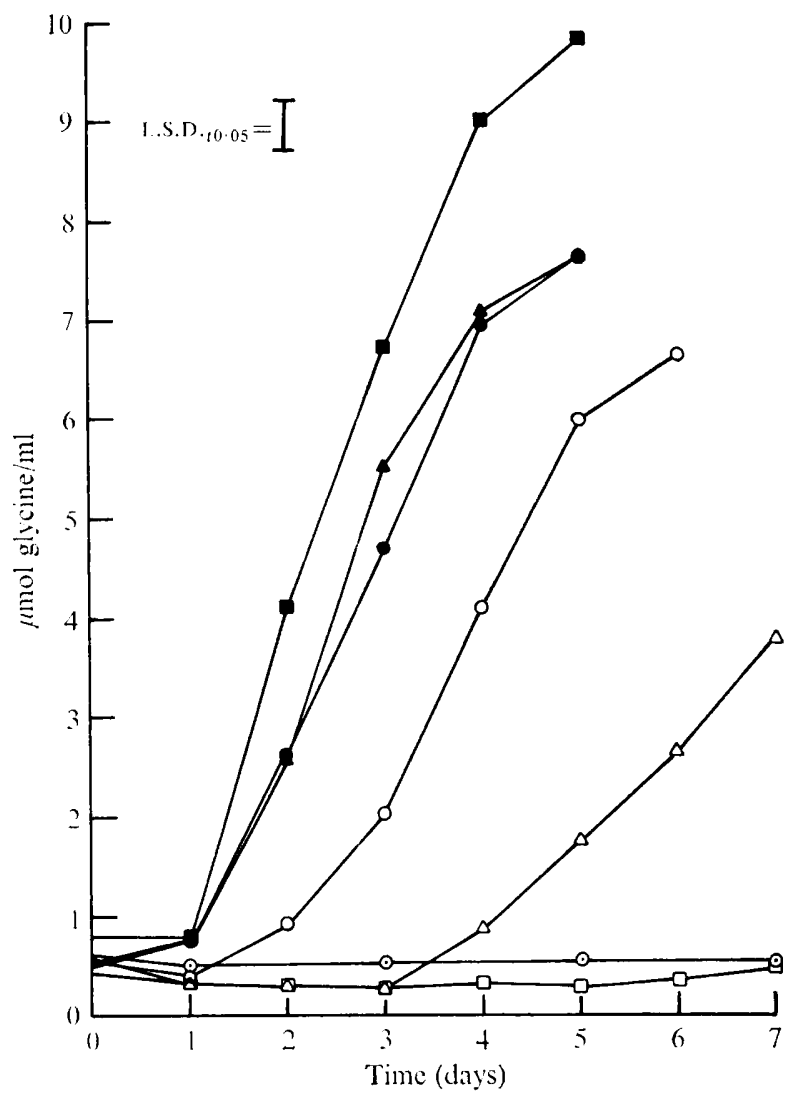

Fig. 2. Collagenolytic activity of Achromobacter iophagus at different $\mathrm{NaCl}$ concentrations. Reaction mixtures, incubated at $30{ }^{\circ} \mathrm{C}$, contained $\mathrm{I} \cdot 5 \mathrm{mg}$ collagen $/ \mathrm{ml}$ of buffer at $\mathrm{pH} 7.6 . \Delta-\mathbf{\Delta}, 0.85 \%$; $\square, 2.34 \% ; \bigcirc-1,0 \% ; \bigcirc-0,7.0 \% ; \triangle-\triangle, 10.0 \% ; \square-\square, 13.0 \% ; \odot-\odot$, control. For method see Fig. 1 and text.
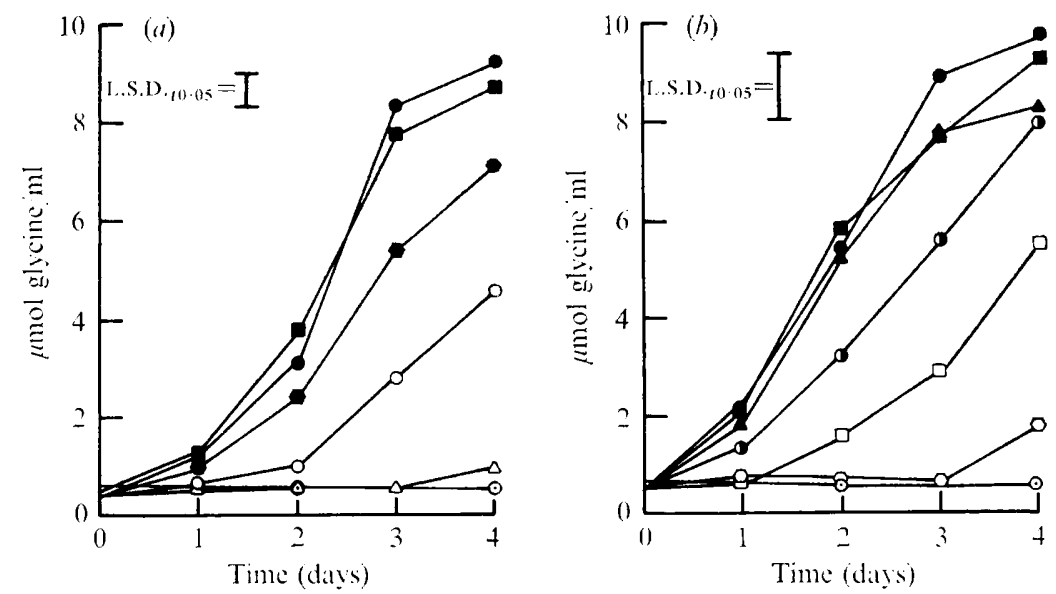

Fig. 3. Collagenolytic activity of Achromobacter iophagus at different $\mathrm{pH}$ values. Reaction mixtures, containing $2.34 \% \mathrm{NaCl}$ and $1.5 \mathrm{mg}$ collagen $/ \mathrm{ml}$, were incubated at $30{ }^{\circ} \mathrm{C} . \triangle-\triangle, \mathrm{pH} 6.0 ; O-O$,

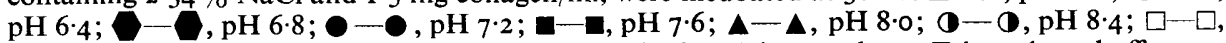
pH 8.8; $\bigcirc-\mathrm{O}, \mathrm{pH} \mathrm{9.2; \odot - \odot ,} \mathrm{control.} \mathrm{For} \mathrm{method} \mathrm{see} \mathrm{Fig.} \mathrm{I} \mathrm{and} \mathrm{text.} \mathrm{Tris-maleate} \mathrm{buffer} \mathrm{was}$ used for $\mathrm{pH}$ values $6 \cdot 0$ to $7 \cdot 6(a)$, and tris- $\mathrm{HCl}$ for $\mathrm{pH}$ values $7 \cdot 2$ to $9 \cdot 2(b)$. 


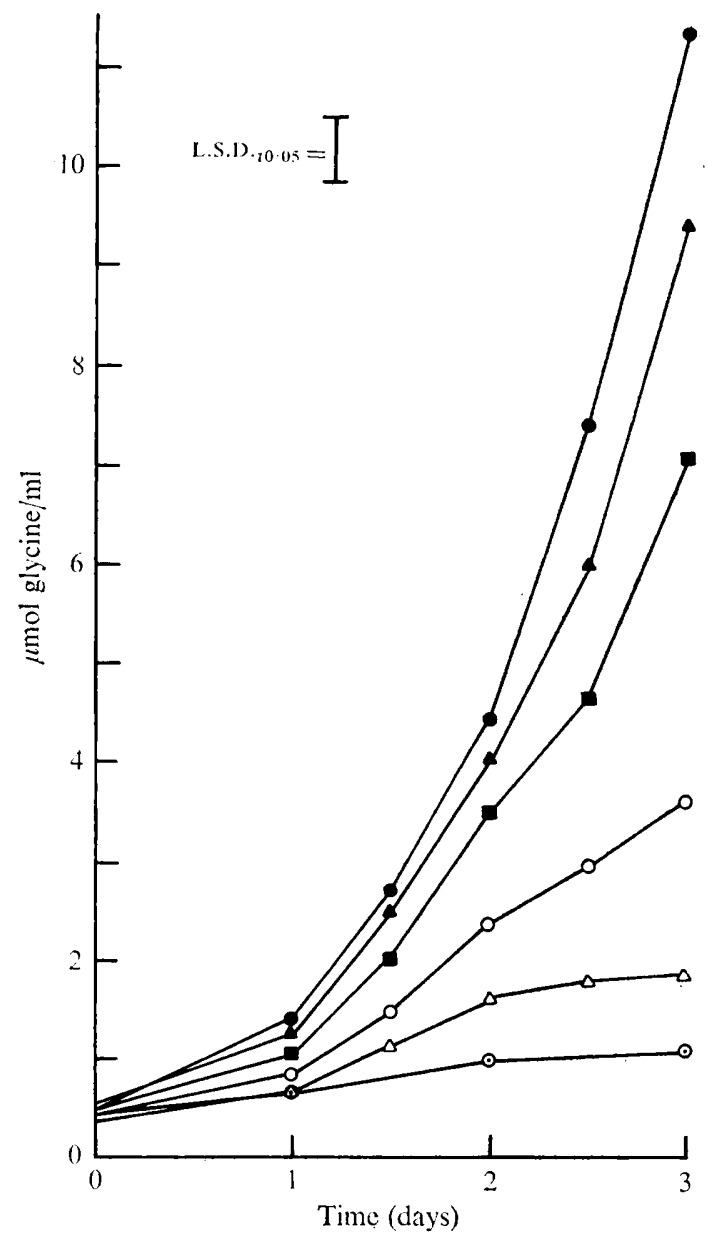

Fig. 4. Collagenolytic activity of Achromobacter iophagus at different collagen concentrations. Reaction mixtures, incubated at $30{ }^{\circ} \mathrm{C}$, contained $2 \cdot 34 \% \mathrm{NaCl}$ and were adjusted to $\mathrm{pH} 7 \cdot 6$.

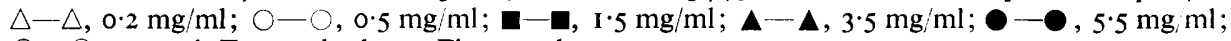
$\odot-\odot$, control. For methods see Fig. I and text.

Effect of collagen concentration. Activity at different collagen concentrations is shown in Fig. 4. Collagenolytic activity increased as the collagen concentration was raised from $0 \cdot 2$ to $5.5 \mathrm{mg} / \mathrm{ml}$.

\section{DISCUSSION}

Achromobacter spp. isolated from hides are among the few bacteria which produce collagenase aerobically (Thomson et al. 1972). Under optimal conditions the present strain of Achromobacter iophagus exhibited an extremely rapid aerobic degradation of collagen with a short lag period. Deviation from optimal conditions resulted in either an increased lag or a reduced activity or both. When only one parameter was varied the bacterium was collagenolytic at 15 to $35^{\circ} \mathrm{C}$ at 0.85 to $10.0 \% \mathrm{NaCl}$ and at least $\mathrm{pH} 6.4$ to 8.8 . The activity increased with collagen concentration over the range studied. It is therefore feasible that this strain could be responsible for significant decay in a hide poorly cured or subjected to an extended period of delayed curing (Cooper, Galloway \& Woods, 1972). 
This is the first report of a hide bacterium with collagenolytic activity at high $\mathrm{NaCl}$ concentrations, which implies a halotolerant collagenase.

This work was supported by a research grant from the South African Council for Scientific and Industrial Research and R. L.W. wishes to acknowledge a research bursary from the Livestock and Meat Industries Control Board.

\section{REFERENCES}

Adamcic, M. \& Clark, D. S. (1970). Collagenolytic activity of pigmented pseudomonads. Canadian Journal of Microbiology 16, 709-7I 2.

Breed, R. S., Murray, E. G. D. \& Sмith, N. R. (1957). Bergey's Manual of Determinative Bacteriology, 7 th edn. Baltimore: Williams and Wilkins.

Cooper, D. R., Galloway, A. C. \& Woods, D. R. (1972). A new look at delayed curing based on the rate of salt penetration and bacterial activity. Journal of the Society of Leather Trades Chemists 56, $127-138$.

Kono, T. (1968). Purification and partial characterization of collagenolytic enzymes from Clostridium histolyticum. Biochemistry 7, I 106-I I 14.

Schaub, M. C. \& Strauch, L. (1968). Purification of Collagenase, IV. Separation and identification of clostridial collagenases by disc electrophoresis on polyacrylamide gel. Hoppe-Seyler's Zeitschrift fiir physiologische Chemie 349, 809-8I 5.

Skerman, V. B. D. (1967). A Guide to the Identification of the Genera of Bacteria with Methods and Digest of Genetic Characteristics, 2nd edn. Baltimore: Williams and Wilkins.

Thomson, J. A., Woods, D. R. \& Welton, R. L. (1972). Collagenolytic activity of aerobic halophiles from hides. Journal of General Microbiology 7o, 315-3I9.

Waldvogel, F. A. \& Swartz, M. N. (1969). Collagenolytic activity of bacteria. Journal of Bacteriology $\mathbf{9 8}$, $662-667$.

Woods, D. R., Welton, R. L., Thomson, J. A. \& Cooper, D. R. (1972). Collagenolytic activity of cured hide bacteria. Journal of Applied Bacteriology 35, I23-1 28. 